Vol.61: e18160419, 2018

http://dx.doi.org/10.1590/1678-4324-2018160419

ISSN 1678-4324 Online Edition
BRAZILIAN ARCHIVES OF

BIOLOGY AND TECHNOLOGY

AN INTERNATIONAL JOURNAL

\title{
Pandan (Pandanus sp), Rotan (Calamus sp), and Rengas (Gluta sp) from Kajuik Lake, Riau Province, Indonesia
}

\author{
Dewi Indriyani Roslim ${ }^{1 *}$. \\ ${ }^{1}$ Department of Biology, Faculty of Mathematics and Natural Sciences, Riau University, Kampus Binawidya Km \\ 12.5, Jl. HR Soebrantas, Panam, Pekanbaru 28293, Indonesia
}

\begin{abstract}
Pandan (Pandanus sp), Rotan (Calamus sp), and Rengas (Gluta sp) are the three most important plants growing at Kajuik Lake, Langgam, Riau Province, Indonesia; however, their species names have not been identified. This study aimed to identify their species names using nuclear internal transcribed spacer(ITS) and psbA-trnH intergenic spacer sequences. The method employed was DNA isolation from fresh leaves, PCR using primer pairs of ITS region for Pandanus sp and psbA-trnH intergenic spacer for Calamus sp and Gluta sp, electrophoresis, sequencing, and data analysis using BLASTn program and MEGA software version 6.0. Pandanus tectorius was the only one accession that was similar to Pandanus sp with the identity was $90 \%$, however the query cover was too small, only $39 \%$. On the contrary, Calamus sp showed the highest genetic similarity to Calamus travancoricus, but in fact, both were differed morphologically. There was no database of psbA-trnH intergenic spacer sequence available for species in Gluta. In conclusion, the species names for those plants still could not be determined. It because they might be the identified plants but their sequences databases were not available in large quantities or they were new species which had never been identified and published in public database.
\end{abstract}

Key words: Calamus sp, Gluta sp, ITS, Pandanus sp, psbA-trnH intergenic spacer.

\footnotetext{
*Author for correspondence: zahra_iin@yahoo.com, iinroslim@gmail.com
} 


\section{INTRODUCTION}

Pandan (Pandanus sp), Rotan (Calamus sp), and Rengas (Gluta sp) are the three most important plants growing at Kajuik Lake, Langgam, Pelalawan Regency, Riau Province, Indonesia. They play a role to maintain the quality and the quantity of water in the river, to resist erosion, as a source of nutrients for fishes in the river, as well as to support a life of water animals, birds, insects, and others $\left[^{1,2,3,4}\right]$. In addition, those are also important for humans, for instances, Pandan as the raw for making pandanus mats, medicines, food flavorings and colorings, while Rotan as the raw material for furniture and Rengas as making buildings $\left[{ }^{5,6,7}\right]$.

Those plants are recently identified at genus-level where the identification is based on morphological characteristics $\left[{ }^{8}\right]$. It needs to do further studies for species-level identifying because the determination of species name correctly is a fundamental thing which is important for the next studies, for examples, the study of physiology, biochemistry, genetics, economic values, etc. so that the plants can be used more widely.

Normally, the approach for plant identification is done based on morphological characteristics [9;10;11;12 ] because it is easier, faster, and cheaper, yet this approach has some limitations or constraints. The obstacles encountered in the earlier identification of those plants is the difficulty in finding the complete organs of the plants especially the flowers and the fruits because the plants bloom and produce fruit in rainy season during which the water surface of Kajuik Lake is high so that the access to go there is not available $\left[{ }^{8}\right]$.

Today, there is a new approach for determination or classifying of species, called DNA barcoding, using a short piece of DNA from the investigated organism genome. Since it was first discovered in 1993 until now, the DNA barcoding has been developed and used to identify various organisms $\left[{ }^{13 ; 14 ; 15}\right]$. This approach has become a promising technique and a new great hope for non taxonomists. The DNA barcoding technique is developed because of the difficulty in identifying some of the specimens which were morphologically indistinguishable, not intact or damage, and reproductive organs can not be found. Even an expert is not able to identify the specimen as it is. Following the discovery of DNA barcoding, non taxonomists can identify some specimens $\left[{ }^{13}\right]$. Two sequences, i.e. $r b c L$ and $m a t K$ genes, have been assessed and recommended as the barcodes for molecular identification of plant specimens $\left[{ }^{16},{ }^{17}\right]$. Some other barcodes have also been developed for molecular identification necessity of higher plants, like the nuclear internal transcribed spacer (ITS) region [18;19], matK [16,17,20], and $p s b A$-trnH intergenic spacer region [19,21,22].

The DNA sequence of ITS region is positioned in nuclear genome that is separated or located between genes coding 18S rRNA, 5.8S rRNA, and 26S rRNA. The number of ITS sequence in plant nuclear genome is abundant or multicopy and its universal primer is available [23], so it is easy to be amplified; therefore, it is often used to identify plants [24]. The $p s b A$-trnH intergenic spacer region and matK gene

are located in plant chloroplast genome (cpDNA) and are commonly used to identify plants [24]. The $p s b A$-trnH intergenic spacer region has high variability between species and is easy to be applied in angiosperms, gymnosperms, ferns, moss, and liverworts [19,22]. The matK gene is encoding maturaseK protein and has high subtitution mutation levels so that it is frequently used in plant phylogenetic analysis [25].

This study reports identification of the three plants from Kajuik Lake using ITS region and $p s b A$-trnH intergenic spacer sequences. 


\section{MATERIALS AND METHODS}

\section{Materials}

The plant materials used in this study were Pandan (Pandanus sp), Rotan (Calamus $\mathrm{sp)}$, and Rengas (Gluta sp) plants. The plants samples were taken from Kajuik Lake, Kampar River, Langgam, Pelalawan Regency, Riau Province, Indonesia.

The primer pairs used in this study were designed based on the DNA sequence available in GenBank database, i.e: ITS_F: 5'-ATC CTG CCT AGC AGA ATG AC3', ITS_R: 5'-GCG TTG GTA AAG AGC AGA TT-3', and psbA-trnH_F: 5'-TGT CGA AGC TCC ATC TAC AA-3', and psbA-trnH_R: 5'-TTG ATC CAC TTG GCT ACA TC-3'.

\section{Total DNA Isolation}

The total DNA was extracted from the fresh leaves of each plant sample using DNeasy plant mini kit (Qiagen). The quality and the quantity of DNA were predicted using electrophoresis on $1.2 \%$ agarose gel in $1 \mathrm{X}$ TBE buffer (Tris-Borate-EDTA pH 8.0) at 65 volts for 30 minutes.

\section{DNA Amplification using PCR (Polymerase Chain Reaction) Techique}

The total DNA of Pandan (Pandanus sp) was amplified using primer pair of ITS_F/ITS_R, while Calamus sp and Gluta sp were amplified using a primer pair of $p s b \bar{A}$-trnH_F/psbA-trnH_R.

Amplification was performed in $50 \mathrm{ul} \mathrm{PCR}$ reaction with the following components: 1X PCR buffer (plus $\mathrm{Mg}_{2+}$ ), $0.1 \mathrm{mM}$ dNTPs, $2.4 \mu \mathrm{M}$ primer forward, $2.4 \mu \mathrm{M}$ primer reverse, 2 U enzim Dream Taq DNA polymerase (Thermo Scientific), and 1 ng DNA total, and water [26]. The PCR analysis was performed with the following conditions: 5 minutes at $94{ }^{\circ} \mathrm{C}$ for 1 cycle followed by 45 seconds at $94{ }^{\circ} \mathrm{C}, 45$ seconds at $47^{\circ} \mathrm{C}$, and 1 minute at $72{ }^{\circ} \mathrm{C}$ for 35 cycles, and ended with 1 cycle of post-PCR for 10 minutes at $72{ }^{\circ} \mathrm{C}$.

\section{Electrophoresis}

The PCR products were then migrated at $1.2 \%$ agarose gel in $1 \mathrm{X}$ TBE buffer, at 65 volts for 1 hour. The gel was soaked in $5 \mu \mathrm{g} / \mathrm{ml}$ ethidium bromide solution to stain the DNA and then the DNA bands were observed under the UV lamp transilluminatior (WiseUv WUV-M20, Daihan Scientific) and were documented using a digital camera (Olympus SP-500 UZ).

\section{PCR Purification and Sequencing}

Sequencing was performed to determine the precise order of nucleotides within a DNA molecule. The PCR products were then sent to PT Genetika Science in Jakarta to be purified and sequenced at 1 st Base Malaysia in two directions using the PCR primer pairs.

\section{Data Analysis}

The DNA sequences were analyzed and aligned using MEGA software version 6.06 (Build\#: 6140226) (Molecular Evolutionary Genetics Analysis) and BLASTn program (Basic Local Alignment Search Tool) at http://www.ncbi. nlm.nih.gov/ BLAST [27].

\section{RESULTS}


Total DNA Molecules and DNA Fragment of ITS and psbA-trnH Intergenic Spacer Regions

In this study the total DNA from Pandanus sp, Calamus sp, and Gluta sp was intact, not degraded, and sufficient for PCR processing (Fig. 1). The PCR product of ITS region of Pandanus sp was 559 bp, psbA-trnH intergenic spacer region of Calamus sp was $670 \mathrm{bp}$, and Gluta sp was 639 bp (Fig. 2). Those were sufficient for the sequencing process requirement.

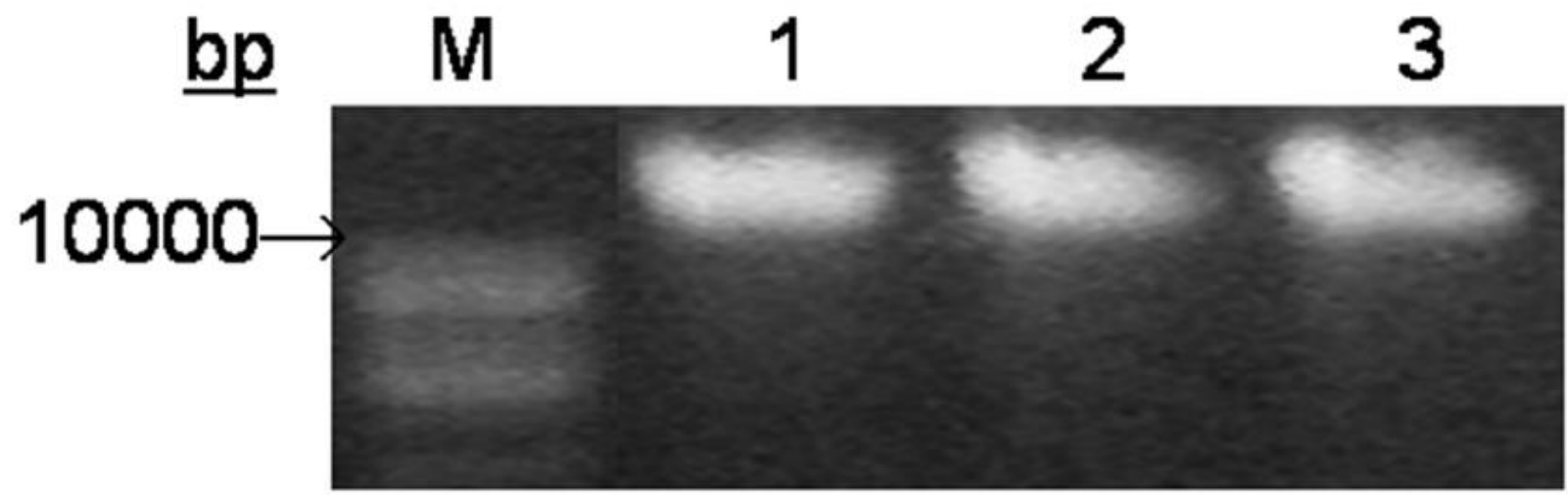

Figure 1. Total DNA molecules of (1) Pandanus sp, (2) Calamus sp, and (3) Gluta sp that migrated on 1.2\% agarose gel in $1 \mathrm{X}$ TBE buffer. (M) $1 \mathrm{~kb}$ DNA Ladder.

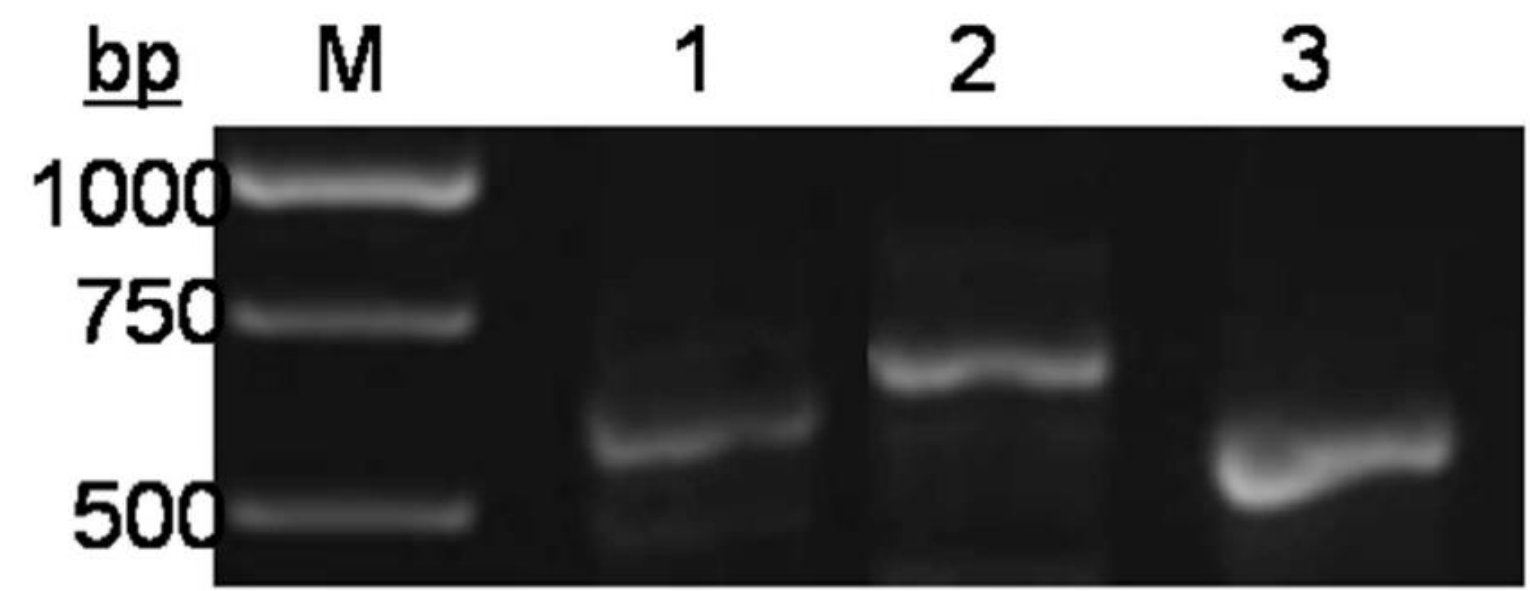

Figure 2. The DNA fragment of ITS of Pandanus sp and psbA-trnH intergenic spacer region of Calamus $\mathrm{sp}$ and Gluta sp that migrated on $1.2 \%$ agarose gel in $1 \mathrm{X}$ TBE buffer. (M) 1 kb DNA Ladder, (1) Pandanus sp,

(2) Calamus sp, and (3) Gluta sp.

Pandan (Pandanus sp) from Kajuik Lake, Kampar River, Pelalawan Regency, Riau Province, Indonesia

The DNA sequence of ITS sizing 599 bp of Pandanus sp had been obtained (GenBank accession number: KX304062) (Fig. 3) and its BLASTn analysis also had been performed (Table 1). 


\begin{abstract}
>Pandanus sp, 18S ribosomal RNA gene, partial sequence; internal transcribed spacer 1, 5.8S ribosomal RNA gene, and internal transcribed spacer 2, complete sequence; and $26 \mathrm{~S}$ ribosomal RNA gene, partial sequence ATCCTGCCCTGCAGAATGACCAGAGAACCGGTAACAAACTCAATGGAGACGGTGGGCCTC GCCCAACGTCTCTAGACGCTTGGATGGCACGGGTGCCTACGGGCGCTCGGGCTTTTTCTC GGCGGCACAACGAACCCCGGCGCGGAATGCGCCAAGGAACTTTAACAAGAGAGCGATGCT CCCGCCGCCCCAGACATGGTGCGTGTGCGGGATGCCATGCAATCTCCTATTATTCATAAC GACTCTCGGCAACGGATATCTCGGCTCTCGCATCGATGAAGAACGTAGCGAACTGCGATA CTTGGTGTGAATTGCAGAATCCCGTGAACCATCGAGTCTTTGAACGCAAGTTGCGCCCGA AGCTTCGGCTGAGGGCACGTTTGCCTGGGTGTCACACATGGCGTTGCCCCTAACCCCTCG CCTTGAATTGGGCGGGCGGGACTTGGGTGCGTACGTTGGCCTCCCGAGATGACCTTATCC CGGTTGGCCCAAAATCGAGCGTCGGAGCGATTAGCACCACGACATTCGGTGGTTGATGAG ACCCCAGTGATCAATGTCG
\end{abstract}

Figure 3. The ITS sequence of Pandanus sp from Kajuik Floodplain Lake, Kampar Floodplain River, Pelalawan District, Riau Province, Indonesia.

Table 1. The alignment analysis using BLASTn of the ITS sequence of Pandanus sp from Kajuik Lake, Kampar River, Pelalawan Regency, Riau Province, Indonesia.

\begin{tabular}{|c|c|c|c|c|c|}
\hline Description & $\begin{array}{l}\text { Total } \\
\text { score }\end{array}$ & $\begin{array}{l}\text { Query } \\
\text { cover }\end{array}$ & E value & Ident & Accession \\
\hline $\begin{array}{l}\text { Pandanus tectorius voucher RBGB } 20031134-52246 \\
\text { (BR) } 18 \mathrm{~S} \text { ribosomal RNA gene, partial sequence; } \\
\text { internal transcribed spacer } 1,5.8 \mathrm{~S} \text { ribosomal } \\
\text { RNA gene, and internal transcribed spacer } 2 \text {, } \\
\text { complete sequence; and } 26 \mathrm{~S} \text { ribosomal RNA } \\
\text { gene, partial sequence }\end{array}$ & 283 & $39 \%$ & $3 e-66$ & $90 \%$ & EU816709.1 \\
\hline
\end{tabular}

The results showed that Pandanus tectorius was the only one accession that was similar to Pandanus sp from Kajuik Lake with identity was $90 \%$, however other parameters value was too small, such as $\max$ score $=246$, total score $=283$, query cover $=39 \%$, and E-value $=3 \mathrm{e}-66$. Moreover, the search for Pandanus ITS sequence in GenBank showed there was only one the database that was Pandanus tectorius property (updated in April 24th, 2016). Further analysis showed that the genetic distance between Pandanus sp from Kajuik Lake and P. tectorius was 1.01. Hence there is still a relatively far distance between Pandanus sp and P. tectorius, then the exact species name of Pandanus sp from Kajuik Lake still could not be determined. The general description of the morphological characteristics of Pandan (Pandanus sp) from Kajuik Lake was described as in the following: shrub; spines on the edge of leaves and the main leaf vein of the beneath leaf surface; leaves forming terminal crown; the upper leaf surface was green and the beneath leaf surface was yellowish green; the male flower was yellow and it emerged on the central of leaf crown; and dioecious (Fig. 4). 


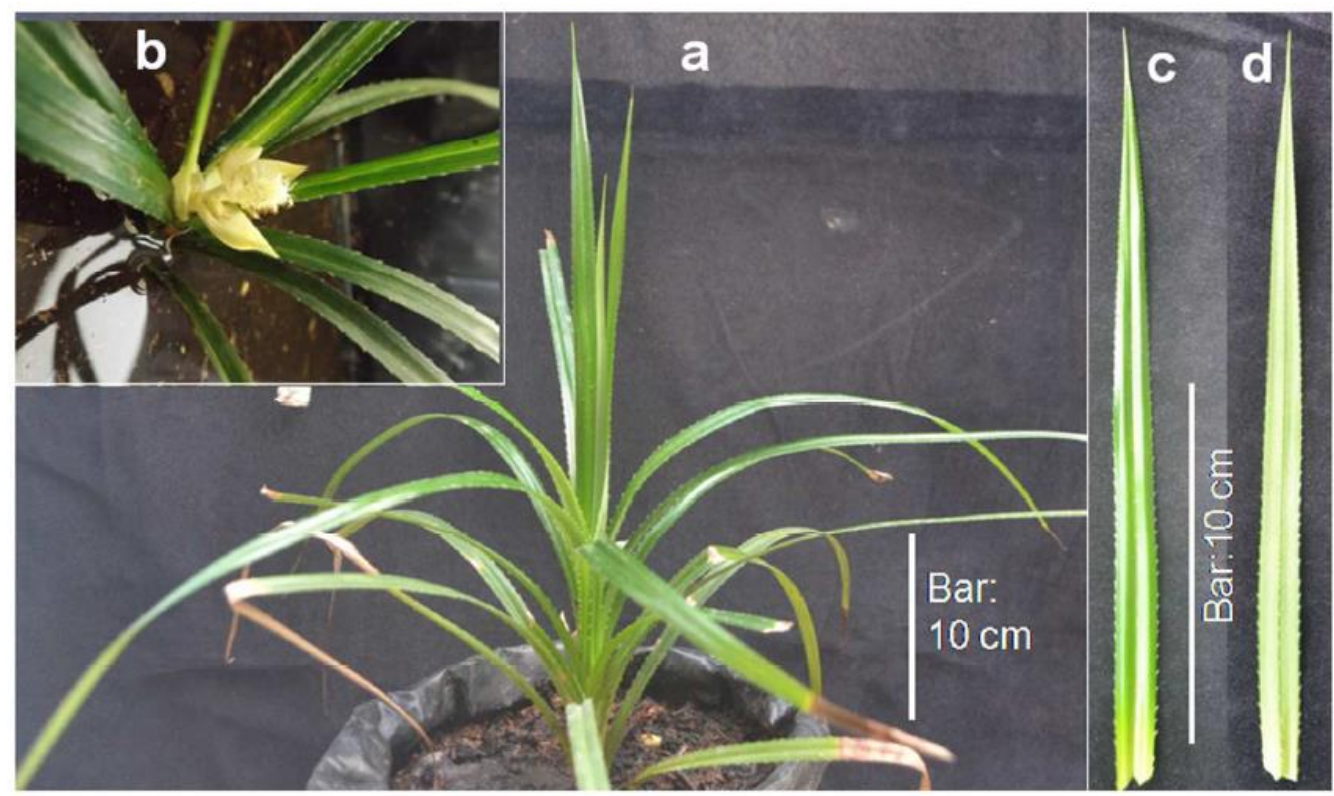

Figure 4. The morphology of Pandanus sp plant from Kajuik Floodplain Lake, Kampar Floodplain River, Pelalawan District, Riau Province, Indonesia. (a) Pandanus sp plant (bar: $10 \mathrm{~cm}$ ), (b) male flower, (c) the upper leaf surface, and $(\mathrm{d})$ the beneath leaf surface (bar: $10 \mathrm{~cm}$ ).

\title{
Rotan (Calamus sp) from Kajuik Lake, Kampar River, Pelalawan Regency, Riau Province, Indonesia
}

The psbA-trnH intergenic spacer sequence sizing $670 \mathrm{bp}$ of Rotan (Calamus sp) had been obtained (GenBank accession number: KX304063) (Fig. 5) and the alignment analysis using BLASTn program had been performed (Table 2). The results showed that there was a high similarity (99\%) between Calamus sp from Kajuik Lake and some accessions of Calamus. Other parameters were also showing the high value. However, the genetic distances between Calamus sp and those accessions were relatively far (Table 3). Consequently, the phylogenetic tree did not show a close relationship between Calamus sp from Kajuik Lake and those Calamus. The examples of a close relationship were between $C$. viminalis and $C$. henryanus; $C$. bonianus and C. karinensis; and C. laccifer and C. basui (Fig. 6).

\begin{abstract}
$>$ Calamus sp, photosystem II protein (psbA) gene, partial cds; psbA-trnH intergenic spacer, complete sequence; and tRNA-His (trnH) gene, partial sequence; chloroplast GACCTAGCTGCTGTCGAAGTTCCATCTACAAATGGATAAGGCTTTTGTCTTAGTGTATAC GAATCGTTGAATCAAACAATGGAGCAATACCCAACTGAAACAAGATATTGCTCCATTGTT TGATTCAGTAGTGTTTTGTATTCAGTTGTGTTTTGCACACAACACATACACATAAATAAG TATTAATAAGTAAGAATTTTTATTTTCATTATTTTTTTTTCTATTTATATATTTCTATTA ATATTTAATATTCAAAAATATTATGAAAATTTCAATAATTTAATTTAACGACGAGATTTA TTGTCGTTTCTTGCATGTCTCGCGAAAGTCAGATTGGGCGCGAATTCTCCCAATTTGTGA CCTACCATACGATCTGTTATATAAATAGGTAAATGTTCCTTTCCATTATGAATAGCGATT GTATGGCCAATCATTGTGGGTATAATGGTAGATGCCCGAGACCAAGTTACTATTATTTCT TTCTCCTCCCTCATGTTGAGTTTTTCAATTTTTCCCGATAAATGATTAGCTACAAAAGGA TTTTTTTTTAGTGAACGTGTCACAGCTGATTACTCCTTTTTTTTACATTTTAAAGATTGG CATTCTATGTCCAATATCTCGATCTAAGTATGGAGGTCAGAATAAATACAATAATGATGA ATGAAAAAAG
\end{abstract}

Figure 5. The psbA-trnH intergenic spacer sequence of Rotan (Calamus sp) from Kajuik Floodplain Lake, Kampar Floodplain River, Pelalawan District, Riau Province, Indonesia. 


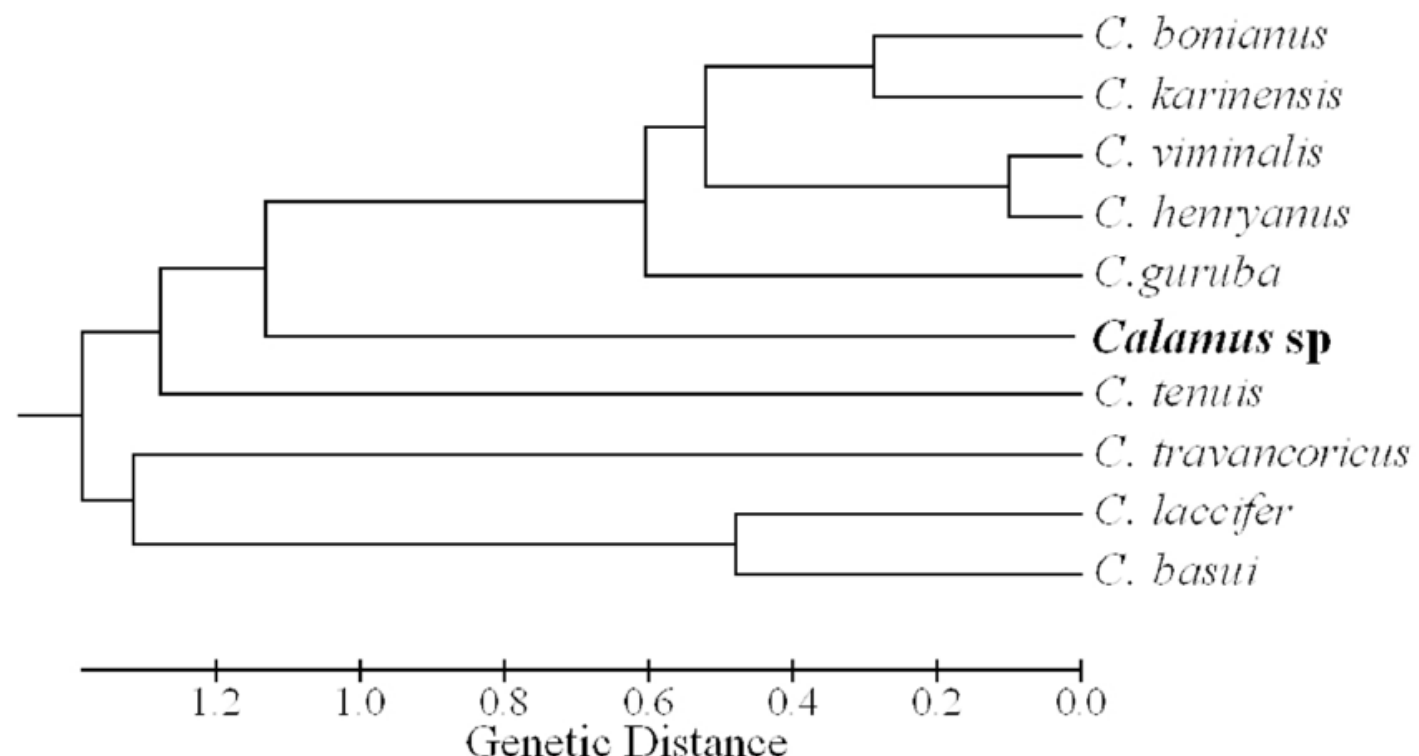

Figure 6. Dendrogram based on psbA-trnH intergenic spacer sequence of some species in Calamus using UPGMA method.

Table 2. The alignment analysis using BLASTn program of $p s b A$-trnH intergenic spacer sequence of Rotan (Calamus sp) from Kajuik Lake, Kampar River, Pelalawan Regency, Riau Province, Indonesia.

\begin{tabular}{|c|c|c|c|c|c|c|}
\hline Description & Max score & $\begin{array}{l}\text { Total } \\
\text { score }\end{array}$ & $\begin{array}{l}\text { Query } \\
\text { cover }\end{array}$ & E value & Ident & Accession \\
\hline $\begin{array}{l}\text { Calamus travancoricus photosystem II protein } \\
\text { (psbA) gene, partial cds; } p s b A-t r n H \text { intergenic } \\
\text { spacer, complete sequence; and tRNA-His }(\operatorname{trnH}) \\
\text { gene, partial sequence; chloroplast }\end{array}$ & 1180 & 1236 & $99 \%$ & 0.0 & $99 \%$ & JX502815.1 \\
\hline $\begin{array}{l}\text { Calamus guruba voucher KUN:Yanghq0057 } \\
\text { PsbA (psbA) gene, partial cds; and psbA-trnH } \\
\text { intergenic spacer, partial sequence; chloroplast }\end{array}$ & 1166 & 1216 & $99 \%$ & 0.0 & $99 \%$ & JQ042114.1 \\
\hline $\begin{array}{l}\text { Calamus karinensis voucher KUN:Yanghq0048 } \\
\text { PsbA (psbA) gene, partial cds; and psbA-trnH } \\
\text { intergenic spacer, partial sequence; chloroplast }\end{array}$ & 1164 & 1219 & $99 \%$ & 0.0 & $99 \%$ & JQ042106.1 \\
\hline
\end{tabular}

Table 3. The genetic distance matrix of Rotan (Calamus) from Kajuik Lake and some accessions in Calamus based on the $p s b$-trnH intergenic spacer sequence.

\begin{tabular}{llllllllll}
\multicolumn{1}{c}{ Accessions } & 1 & 2 & 3 & 4 & 5 & 6 & 7 & 8 & 9 \\
\hline 1. Calamus sp & - & & & & & & & & \\
2. C. laccifer & 2.39 & - & & & & & & & \\
3. C. basui & 2.38 & 0.96 & - & & & & & & \\
4. C. bonianus & 2.34 & 3.76 & 2.41 & - & & & & & \\
5. C. guruba & 2.32 & 3.42 & 2.62 & 1.20 & - & & & & \\
6. C. viminalis & 2.40 & 2.72 & 2.58 & 0.77 & 1.27 & - & & & \\
7. C. henryanus & 2.32 & 2.41 & 2.44 & 1.36 & 1.19 & 0.20 & - & & \\
8. C. karinensis & 1.92 & 3.36 & 2.52 & 0.58 & 1.17 & 0.76 & 1.28 & - & \\
9. C. tenuis & 3.52 & 2.62 & 2.65 & 3.36 & 1.59 & 2.49 & 1.99 & 2.39 & - \\
10. C. travancoricus & 3.54 & 2.85 & 2.41 & 2.78 & 2.58 & 2.65 & 2.50 & 2.35 & 3.54 \\
\hline
\end{tabular}

Although the database of psbA-trnH intergenic spacer sequence of genus Calamus had already been available in GenBank sufficiently, i.e 158 database (updated in April 24th, 2016), unfortunately there was no one of the database that was similar to the Calamus 
sp sequence. Thus, the exact species name of Calamus sp from Kajuik Lake still could not be determined.

The general description of the morphological characteristics of Calamus sp from Kajuik Lake were described as in the following: the young leaves were yellow and then changed into green of the mature leaves; spines or thorns at the base of green stem and at the vein on the beneath leaf surface; 88 small fruits were arranged in bunches; the immature fruits were green and scaly and the mature fruits were brown and scaly; $1.5 \mathrm{~cm}$ fruit diameter and $4.5 \mathrm{~cm}$ fruit circumference (Fig. 7).

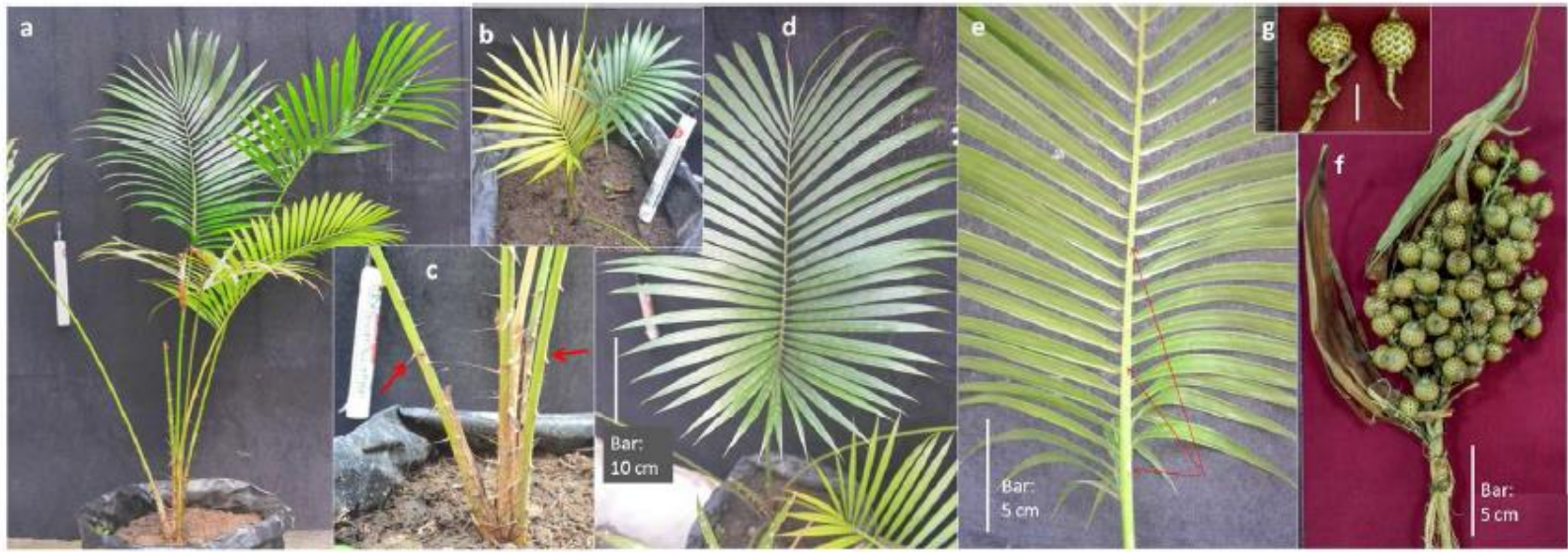

Figure 7. The morphology of Calamus sp tree from Kajuik Floodplain Lake, Kampar Floodplain River, Pelalawan District, Riau Province, Indonesia. (a) Calamus sp with greeny mature leaves, (b) yellow young leaf, (c) spines at the base of stem $(\rightarrow$ arrow), (d) the upper leaf surface (bar: $10 \mathrm{~cm})$, (e) the beneath leaf surface with spines on the main leaf vein $(\rightarrow$ arrow) (bar: $5 \mathrm{~cm})$, (f) a bunch (bar: $5 \mathrm{~cm})$, and $(\mathrm{g})$ fruits in zoom view (bar: $1 \mathrm{~cm})$.

\section{Rengas (Gluta sp) from Kajuik Lake, Kampar River, Pelalawan Regency, Riau Province, Indonesia}

The length of observed $p s b A-t r n H$ intergenic spacer sequence of Gluta sp from Kajuik Lake was 639 (GenBank accession number: KX304064) (Fig. 8) and it had been aligned using BLASTn program (Table 4). The results showed that there was none of $p s b A$-trnH intergenic spacer sequence of genus Gluta found in the database. The $p s b A$ $\operatorname{trn} H$ intergenic spacer sequence that was available was of another genus but still in the same family as Gluta sp, namely Anacardiaceae. The highly ident value, that was up to $90 \%$, between Gluta sp and those genus, i.e. Anacardiaceae sp, Fegimanra sp, dan Anacardium excelsum showed that Gluta sp from Kajuik Lake was the members of family Anacardiaceae. However, the genetic distance and the clustering analysis did not show the close relationship between them (Table 5 and Fig. 9). Thus, the exact name of Gluta sp still could not be determined. These results forced us to look for other sequences that can be applicable in the Gluta sp identifying. Until now, the DNA sequences database of genus Gluta in GenBank was limited and only trnL-trnF (3 data) and matK (3 data) sequences that was available. 
$>$ Gluta sp, photosystem II protein (psbA) gene, partial cds; psbA-trnH intergenic spacer, complete sequence; and tRNA-His (trnH) gene, partial sequence; chloroplast ССTAACCTTTTTGCTGTCGAAGCTCCATCTACAAATGGATAAGATTTCGGTTTTTGTGTA TACAAGTTTTTGAAAATAACGGAGCAATATTGACCCTTTGCAAGAAATTGGTATTGCTCC GTTATTTAGTAGTTTTTGATTTACATACGTTTCGTTTGGTTGGTTGTTTTGCAACAAAAC AAAATTTTATGCAAATTAATTAATGTTAATATATATTTGATTTCTATAAATAAGAAATCG AAACAATTGATTTCTATCTATTTAATAATAATAATGGAGAATAATATTCTTCTGTATATT AGAATCCATAGAATCTATAATCTATTAGATAAATAGATAAAAATACAACAAAAAAAAATC TAAGAAATTCTTTGAATTTTTAATTCAAATTTAATAATTTACTAATTATTATTTGACTTT TACAGTGAAAAAAAAAATCGAAACGATAAAGGTTGTAGAAAAGAAAAGGATTGAAATTTT CTGCTTCTTGTCTTGTATCTTCACTTCGAGATTGATAAGTAAGGTACCATAAAAAAAGGA GAATGATCAAAAATTATGATCAATGGTAGAAATTGTAATCTTTTGATTTTTTGTAATTTT TTAGGAGGGGCGGATGTAGCCAAGTGGATCAAATCAAAC

Figure 8. The psbA-trnH intergenic spacer seqeuence of Gluta sp from Kajuik Floodplain Lake, Kampar Floodplain River, Pelalawan District, Riau Province, Indonesia.

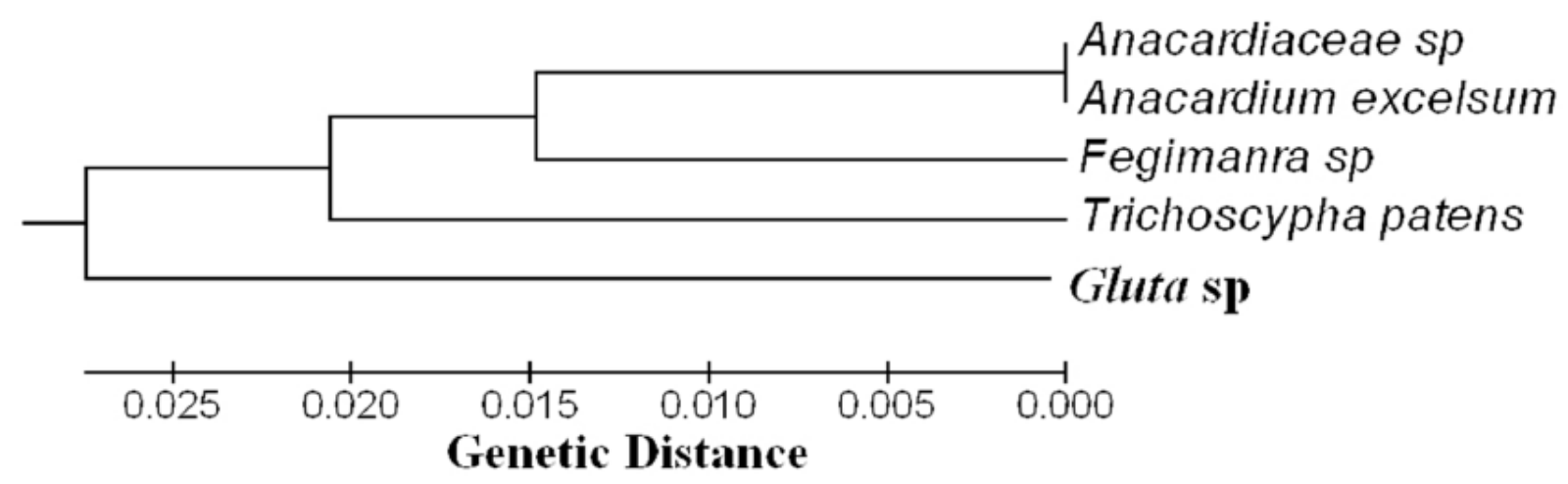

Figure 9. Dendrogram based on psbA-trnH intergenic spacer sequence of some species in Anacardiaceae using UPGMA method.

Table 4. The alignment analysis using BLASTn of $p s b A$-trnH intergenic spacer sequence of Gluta sp from Kajuik Lake, Kampar River, Pelalawan Regency, Riau Province, Indonesia.

\begin{tabular}{|c|c|c|c|c|c|c|}
\hline Description & Max score & $\begin{array}{l}\text { Total } \\
\text { score }\end{array}$ & $\begin{array}{l}\text { Query } \\
\text { cover }\end{array}$ & E value & Ident & Accession \\
\hline $\begin{array}{l}\text { Anacardiaceae sp. NPL0486 chloroplast DNA } \\
\text { containing } p s b A \text {-trnH IGS, specimen voucher } \\
\text { NPL0486 }\end{array}$ & 902 & 947 & $97 \%$ & 0.0 & $91 \%$ & HG964022.1 \\
\hline $\begin{array}{l}\text { Fegimanra sp. Randrianasolo } 843 \text { voucher } \\
\text { Randrianasolo } 843(\mathrm{MO}) \text { PsbA (psbA) gene, } \\
\text { partial cds; and psbA-trnH intergenic spacer, } \\
\text { partial sequence; chloroplast }\end{array}$ & 883 & 927 & $93 \%$ & 0.0 & $92 \%$ & KF664317.1 \\
\hline $\begin{array}{l}\text { Anacardium excelsum voucher Montiel } \\
\text { 32769(MO) PsbA (psbA) gene, partial cds; and } \\
\text { psbA-trnH intergenic spacer, partial sequence; } \\
\text { chloroplast }\end{array}$ & 870 & 915 & $93 \%$ & 0.0 & $91 \%$ & KF664314.1 \\
\hline
\end{tabular}


Table 5. The genetic distance between Rengas (Gluta sp) from Kajuik Lake and some species in Anacardiaceae based on psbA-trnH intergenic spacer sequence.

\begin{tabular}{|c|c|c|c|c|c|}
\hline Accessions & 1 & 2 & 3 & 4 & 5 \\
\hline 1. Gluta $\mathrm{sp}$ & - & & & & \\
\hline 2. Anacardiaceae $\mathrm{sp}$ & 0.06 & - & & & \\
\hline 3. Fegimanra $\mathrm{sp}$ & 0.06 & 0.03 & - & & \\
\hline 4. Anacardium excelsum & 0.06 & 0.00 & 0.03 & - & \\
\hline 5. Trichoscypha patens & 0.05 & 0.04 & 0.04 & 0.04 & - \\
\hline
\end{tabular}

The morphological characteristics of Gluta sp from Kajuik Lake were as in the following: the young leaves were light green, purplish-green, or purple; the mature leaves were green of the upper leaf surface and light green on the beneath leaf surface; the leaves arranged spirally in stem; leaves elliptical or ovoid breech, $8-36 \mathrm{~cm}$ long, 4-9 $\mathrm{cm}$ wide, blunt tip and the surface of the leaves were not hairy; fruit sized like a chicken eggs or larger and coloured reddish-brown and a diameter of about $6 \mathrm{~cm}$; the tree height of about 15 meters with bright stem color like gray and form the root buttresses (Fig. 10).

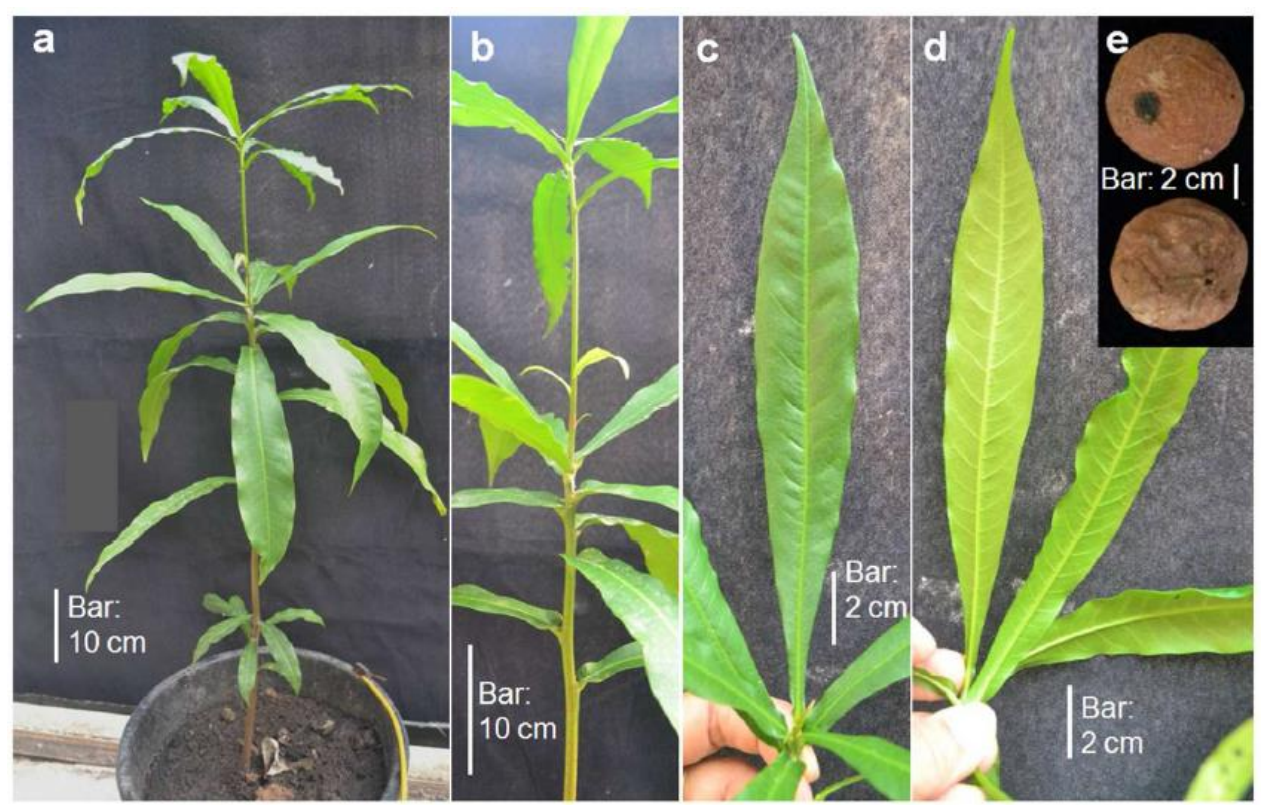

Figure 10. The morphology of Gluta sp from Kajuik Floodplain Lake, Kampar Floodplain River, Pelalawan District, Riau Province, Indonesia. (a) Gluta sp tree (bar: $10 \mathrm{~cm}$ ), (b) the leaves position in stem (bar: $10 \mathrm{~cm}$ ), (c) the upper leaf surface (bar: $2 \mathrm{~cm}),(\mathrm{d})$ the beneath leaf surface (bar: $2 \mathrm{~cm}$ ), and (e) fruits (bar: $2 \mathrm{~cm}$ ).

\section{DISCUSSION}

Genetics studies, like the study of gene expression analysis and identification of gene function, requires objects, for instance, animals, plants, and microbes which are clearly their identity. Before molecular biology technique developed rapidly like today, species identification was performed based on morphological characteristics. In fact, the species identification morphologically has some limitations, for instances, the identification keys are often only suitable for a certain life stage or gender, some taxa are difficult to be identified morphologically, plasticity, and genetic diversity on morphological characters so that it needs a high expertise in the field of taxonomy [28], and also the declining of taxonomist number [24]. Those are encouraging scientists to develop an alternative identification technique based on short nucleotide sequence of 
a genome and it is called DNA barcoding technique. The DNA barcoding permits a non taxonomist to identify even though the specimens are incomplete or broken [13,24,29].

The first step in plant molecular analysis is extracting the total DNA which is then used at the next step such as polymerase chain reaction (PCR) to amplify the target sequences. The PCR product will be a band in electrophoresis gel. The thick and the single bands are suitable for sequencing requirement [30,31].

After that, the sequences are analyzed using BLASTn program at http://ncbi.nih.nlm.gov/.

All parameters in BLASTn analysis are important and they determine the level of similarity between organism observed (query) and the available accessions in a public database (subject). The meaning of some parameters are as follows: Max score shows the similarity score between sequences compared; Query cover is a percentage of the analyzed sequence or a percentage of the aligned sequences; E-value (=The Expectation value) is a probability where the lower the E-value, the more significant the score and the alignment; and Ident shows the level or percentage of similarity at the same position of two sequences aligned where the more the ident value, the higher the similarity level $[27,32,33]$.

In this study, the DNA barcoding was used to identify Pandan (Pandanus sp), Rotan (Calamus sp), and Rengas (Gluta sp) from Kajuik Lake, which were previously identified based on morphological caharacters but failed to determine their species name because of the incomplete organs observed. The identification of Pandanus sp from Kajuik Lake was performed based on ITS. The ITS region as a nuclear ribosomal DNA region was used as a DNA barcode to complement the identification based on chloroplast genes [34]. Moreover, it had big potential for species identification [21] and had already been applied as DNA barcode at interspecies and intraspecies level [35].

Unfortunately, the ITS sequence database for genus Pandanus were still limited, i.e. only one ITS sequence was available. The one ITS sequence was from $P$. tectorius which was the same thorns as Pandanus sp from Kajuik Lake. Yet, BLASTn analysis in this study did not show a close relationship between them and also there was still relatively far distance between both. Therefore, the species name of

Pandanus sp from Kajuik Lake still could not be determined. This result also suggested that might be Pandanus sp from Kajuik Lake was a new species which had never been identified and published.

In this study, the Calamus sp and Gluta sp from Kajuik Lake were identified using $p s b A$-trnH intergenic spacer sequence which was a chloroplast non-coding region and a good DNA barcode in species identification [18]. Until now (updated in April 24th, 2016) 158 psbA-trnH intergenic spacer sequences of Calamus have already been available in public database but none of them are similar to Calamus sp from

Kajuik Lake. In contrast, the $p s b A-t r n H$ intergenic spacer sequence of Gluta in public database was not available, but 3 trnL-trnF sequences and 3 matK sequences of Gluta were available in there.

Nursal et al. [36] reported that one of Anacardiaceae member growing at Rimbo Tujuh Danau forest (which was also part of Kampar River in Riau Province, Indonesia) was Rengas (Gluta renghas). Gluta sp from Kajuik Lake had morphological similarity to that Gluta renghas [37]. The database of psbA-trnH

intergenic spacer sequence of Gluta renghas was not available, but the trnL-trnF and rps16 sequences had already been available in public database (updated in April 24th, 2016). Therefore, Gluta sp identification must be tried using both sequences.

This research showed that this study failed to determine the species name of Pandan (Pandanus sp), Rotan (Calamus sp), and Rengas (Gluta sp) from Kajuik Lake and also 
demonstrated that the identification using DNA barcode, in fact, must be supported by a large number of database.

Furthermore, this research suggested that it might be the plants were the identified plants but their sequences were not available in large quantities or they were new species which were undentified and unpublished in public database. Therefore, further investigation to determine their species name will be performed using other DNA barcodes.

\section{CONCLUSIONS}

DNA barcoding had given new hope to identify plants which were indistinguishable morphologically, not intact or broken, and incomplete organs. Unfortunately, the database of DNA sequences of many plants from many regions of the world including Indonesia have not yet been available in GenBank. This research gave a great contribution to enhance the database of plants, such as Pandan (Pandanus sp),

Rotan (Calamus sp), and Rengas (Gluta sp), from Kajuik Lake particularly and Indonesia in general. It was also emphasized that morphological and molecular identifications were complementary each other and play an important role to build the public database. The public database availability in large quantities allows a person who is not a taxonomist to identify an organism easily.

\section{ACKNOWLEDGMENTS}

This research was fully sponsored by a grant from DIPA of Riau University, Indonesia under 'Penelitian Unggulan Universitas Riau 2016' on behalf of Dr. Dewi Indriyani Roslim. I would like to thank to Putri Nurkhairani, S.Si. and Siti Khumairoh, S,.Si. for their technical assistance in the laboratory.

\section{REFERENCES}

1. Banner A, MacKenzie W. Riparian Areas: Providing Landscape Habitat Diversity, Part 5 of 7. Extension Note. British Columbia: Ministry of Forests Research Program; 1998.

2. Price P, Lovett S. Managing Riparian Land. Fact Sheet 1. Canberra: Land \& Water Australia; 2002.

3. Pease AA, Davis JJ, Edwards MS, Turner TF. Habitat and resource use by larval and juvenile fishes in an arid-land river (Rio Grande, New Mexico). Freshwater Biol. 2006; DOI:10.1111/j.1365- 2427.2005.01506.x.

4. Zeug, SC, Winemiller KO. Relationships between hydrology, spatial heterogeneity, and fish recruitment dynamics in a temperate floodplain river. River Res Applic. 2008; 24: 90-102. DOI: $10.1002 /$ rra.1061.

5. Thomson LAJ, Englberger L, Guarino L, Thaman RR, Elevitch C. Pandanus tectorius (pandanus), ver. 1.1. In: CR Elevitch (ed.). Species Profiles for Pacific Island Agroforestry. Permanent Agriculture Resources (PAR), Holualoa, Hawai. 2006. http://www.traditionaltree.org.

6. Jasni, Krisdianto, Kalima T, Abdurachman. Atlas Rotan Indonesia. Jilid 3. Bogor: Pusat Penelitian dan Pengembangan Keteknikan Kehutanan dan Pengolahan Hasil Hutan; 2012.

7. Supriatna N, Kelana T. Informasi Singkat Benih: Renghas (Gluta renghas L). BPTH Jawa Dan Madura; 2011.

8. Elvyra R, Yus Y. Ikan Lais dan Sungai Paparan Banjir di Provinsi Riau. Pekanbaru: UR Press Pekanbaru; 2010.

9. Pasaribu N. Two new species of freycinetia (pandanaceae) from Sumatra, indonesia. Reinwardtia. 2010; 13(2): 147-150. 
10. da Silva NR, Florindo JB, Gómez MC, Rossatto DR, Kolb RM, Bruno OM. Plant Identification Based on Leaf Midrib Cross-Section Images Using Fractal Descriptors. PLoS ONE. 2015; 10(6): e0130014. doi:10.1371/journal.pone.0130014

11. Sofiyanti N, Mat-Salleh K, Mahmud K, Mazlan NZ, Hasein MRA, Burslem DFRP. Rafflesia parvimaculata (Rafflesiaceae), a new species of Rafflesia from Peninsular Malaysia. Phytotaxa. 2016; 253(3): 207-213.

12. Roslim DI, Herman, Sofyanti N, Chaniago M, Restiani R, Novita L. Characteristics of 22 cassavas (manihot esculenta crantz) from Riau Province, Indonesia. SABRAO J Breed. and Genet. 2016; 48(2): 110-119.

13. Hebert PDN, Cywinska A, Ball SL, deWaard JR. Biological identifications through DNA barcodes. Proc. R. Soc. Lond. B. 2003; 270: 313-321.

14. Hebert PDN, Stoeckle MY, Zemlak TS, Francis CM. Identifi cation of birds through DNA barcodes. PLoS Biol. 2004; 2: e312.

15. Pinto FCJ, de Lima DB, Agustini BC, Dallagassa CB, Shimabukuro MF, Chimelli M, Brand D, Fadel-Picheth CMT, Bonfim TMB. Morphological and molecular identification of filamentous fungi isolated from cosmetic powders. Braz. Arch. Biol. Technol. 2012; 55(6): 897-901.

16. CBOL Plant Working Group. A DNA barcode for land plants. Proc Natl Acad Sci USA. 2009; 106: 12794-12797. doi: 10.1073/pnas. 0905845106 PMID: 19666622.

17. Lahaye, R., Bank, M. V., Bogarin, D., Warner, J., \& Pupulin, F. DNA barcoding the floras of biodiversity hotspots. Proc. Natl. Acad. Sci. USA. 2008; 105: 2923-2928.

18. Pang X, Liu C, Shi L, Liu R, Liang D, Li H, Cherny SS, Chen S. Utility of the trnH-psbA intergenic spacer region and its combinations as plant DNA barcodes: A meta-analysis. PLoS ONE. 2012; 7(11): e48833. doi:10.1371/journal.pone.0048833.

19. Bolson M, Smidt EdC, Brotto ML, Silva-Pereira V. ITS and trnH-psbA as efficient DNA barcodes to identify threatened commercial woody Angiosperms from Southern Brazilian Atlantic rainforests. PLoS ONE. 2015; 10(12): e0143049. doi:10.1371/journal.pone.0143049 20. Yu J, Xue JH, Zhou SL. New universal matK primers for DNA barcoding angiosperms. $J$ Syst. Evol. 2011; 49(3): 176-181. doi: 10.1111/j.1759-6831.2011.00134.x.

21. Kress WJ, Wurdack KJ, Zimmer EA, Weigt LA, Janzen DH. Use of DNA barcodes to identify flowering plants. PNAS. 2005; 102(23): 8369-8374.

22. Kress WJ, Erickson DL. A two-locus global DNA barcode for land plants: The coding rbcL gene complements the non-coding trnH-psbA apacer region. PLoS ONE. 2007; 2: e508

23. White TJ, Bruns TD, Lee SB, Taylor JW. Amplification and direct sequencing of fungal ribosomal RNA genes for phylogenetics. In: PCR Protocols and Application: A Guide to Methods and Applications. Academic Press, Inc. 1990.

24. Ali MA, Gyulai G, Hidve'gi N, Kerti B, Al Hemaid FMA, Pandey AK, Lee J. The changing epitome of species identification - DNA barcoding. Saudi Journal of Biological Sciences. 2014; 21: 204- 231.

25. Patwardhan A, Ray S, Roy A. Molecular markers in phylogenetic studies- A Review. $J$ Phylogen. Evolution Biol. 2014; 2: 131. doi:10.4172/2329-9002.1000131.

26. Porebski S, Bailey LG, Baum BR. Modification of a CTAB DNA extraction protocol for plants containing high polysaccharide and polyphenol components. Plant Mol. Biol. Rep. 1997; 15(1): 8- 15.

27. Altschul SF, Madden TL, Schaffer AA, Zhang J, Zhang Z, Miller W, Lipman DJ. Gapped BLAST and PSI-BLAST: a new generation of protein database search programs. Nucleic Acid Res. 1997; 25: 3389-3402.

28. Jarman SN, Elliott NG. DNA evidence for morphological and cryptic Cenozoic speciations in the Anaspididae, 'living fossils' from the Triassic. J Evol Biol. 2000; 13: 624-633. 29. Stoeckle, M. Taxonomy, DNA, and the bar code of life. BioScience. 2003; 53: 9.

30. Nugraha, F., Roslim, D. I., Ardilla, Y. P. \& Herman. Analisis Sebagian Sekuen Gen Ferritin2 pada Padi (Oryza sativa L.) Indragiri Hilir, Riau. Biosaintifika: Journal of Biology \& Biology Education. 2014; 6(2), 70-79.

31. Roslim DI, Nisa F, Herman. An analysis of partial DNA sequence of Meisal gene on sweet and bitter cassavas (Manihot esculenta Crantz.). Biosaintifika: Journal of Biology \& Biology Education. 2016; 8(1): 103-110. 
32. Fassler J, Cooper P. BLAST Help. Bethesda (MD): National Center for Biotechnology Information (US); 2008.

33. Madden T. The NCBI Handbook, 2nd edition. Bethesda (MD): National Center for Biotechnology Information (US); 2013.

34. Chase MW, Salamin N, Wilkinson M, Dunwell JM, Kesanakurthi RP, Haidar N, Savolainen V. Land plants and DNA barcodes: short-term and long term goals. Philos Trans $R$ Soc B. 2005; 360: 1889-1895.

35. Feliner GN, Larena BG, Aguilar JF. Fine scale geographic structure, intra-individual polymorphism and recombination in nuclear ribosomal internal transcribed spacers in Armeria (Plumbaginaceae). Ann Bot. 2004; 93: 189-200.

36. Nursal, Suwondo, Sirait IN. Karakteristik komposisi dan stratifikasi vegetasi strata pohon komunitas riparian di kawasan hutan wisata Rimbo Tujuh Danau Kabupaten Kampar Provinsi Riau. Jurnal Biogenesis. 2013; 9(2): 39-46.

37.Fern K. Useful Tropical Plants Database. Creative Commons Attribution-NonCommercialShareAlike 3.0 Unported License. 2004 [updated in 2016-04-01]. Available from: http://tropical.theferns.info/image.php?id=Gluta +renghas). 